\title{
Jesus - The immigrant Egyptian Jews in Matthew's Sondergut: A migration perspective
}

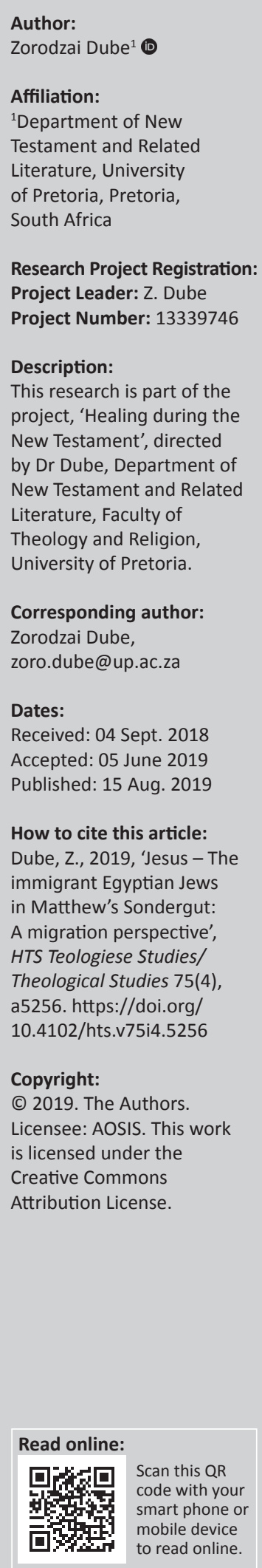

Using pull and push factors inspired by the migration theory, this study explains Matthew's Sondergut concerning Jesus' flight to Egypt from the perspective of possible pull-push factors associated with Egypt and Palestine during the first century. Within early Christianity, two perception strands concerning Egypt existed: on the one hand, Jews such as Celsus depicted Egypt negatively as a place of magic and oppression. Yet another perspective portrays Egypt as a place of refuge, recuperation and recovery - a view reflected in Luke-Acts, Matthew and some parts of Mark. Not disregarding views that read the story as Midrash or allegory, this study focuses on Matthew's Sondergut concerning Jesus' flight to Egypt as narrative explainable from a positive migration perspective, and argues that the prosperity of Egypt and possible political turmoil in Palestine during the first century give plausible reconstruct for Matthew's Sondergut regarding Jesus' flight to Egypt as a place of refuge and sustenance.

Keywords: Egypt; Reception; Refuge; Jesus; Holy Family; Memory.

\section{Introduction}

Theoretical perspectives are our subjective explanations through which we make meaning of events around us. Concerning this, the shift from modernity to postmodernity allows for the acceptance of a multifaceted perspective. In the past and concerning the Bible, only Western sanctioned perspectives were regarded as normative. However, the irony was that Western interlocutors acted seemingly oblivious to the fact that they too were engaged in a contextual reading of the Bible, shaped by their own context(s). Now that hermeneutics or epistemology is not an innocent exercise devoid of idiocy, equally so biblical interpretation is always a search for plausible meaning informed by our context.

My alternative reading of Matthew's Sondergut is informed by recent events of migration across Africa characterised by war and economic hardship. As biblical interpretation is done inter alia with context, migration studies have become one of the new and yet growing interdisciplinary fields across disciplines such as anthropology, sociology and theology. Given that migration is a recurrent theme throughout the Bible, what new insights or questions does it give in understanding narratives such as Jesus' flight to Egypt? In taking this direction of inquiry, I am less interested in the historicity of the story (that is whether it is Midrash of legendary story); instead, focus is on whether push and pull factors inspired by migration theory may make the story more plausible from the readers whose reading lens is informed by immigration issues.

\section{Previous approaches to Matthew's Sondergut}

Before digging into the plausibility of the story from a migration perspective, previous approaches need to be revisited. Two major dominant perspectives exist: firstly that the story is a legendary story and secondly that it is Midrash. The term 'legendary' should not be mistaken for being untrue; instead, similar to many heroic stories, it refers to commonly mysterious stories about great people seen as superhuman. Those who advocate for the story as legendary compare the story with similar stories found in extracanonical writings such as the gospel of Thomas where an Angel talked to Joseph and also rocks and trees talking to baby Jesus (Bourke 1960; France 1981:233). It is in the Infant Gospel of Thomas that we find most reference to legendary material associated with Jesus. For example, in the Infant Gospel of Thomas, Jesus was an extraordinary child who performs miracles. At one point, he healed his brother after he had been bitten by a snake. In addition, after being angered at school, he cursed the teacher who later fell sick and died (Aasgaard 2009:86). Besides the Infant Gospel of Thomas, W.D. Davies and D.C. Allison confirm the existence of similar mythological stories such as 'Gilgamish, sargon, Zoroaster (who like Jesus

Note: HTS 75th Anniversary Maake Masango Dedication. 
was allegedly visited by adoring magi), Cyrus, Appolo, Perseus, Hercules, Romulus and Remus ...' (Davies \& Allison 2004:258). Far from being defined as untrue, legendary stories function to reinforce to followers of such persons that their leader is a supernatural being. They have identity formation purpose to followers that their community has supernatural affirmation.

The second dominant view is that the story is Midrash, meaning that it is the reinterpretation of past shared events now being seen as repeating themselves. In the Old Testament, Israel traces its origin to Egypt - a place associated with shared community trauma but also hope as Moses led them and founded the nation of Israel. Similarly, as Matthew's community finds itself at the crossroads of being accused of being a Syrian Jewish Hellenistic sect within Judaism, the community needed to redefine itself as a true continuation of Israel and authentic keepers of the Torah. To cement their history as legitimate, like Moses, their leader Jesus is the new Moses.

During his famous Sermon on the Mount, like Moses Jesus goes to Egypt and reinterprets the Torah (Mt 5) (Bourke 1960; France 1981:233). Concerning this, Davies and Allison make two crucial comments - first that, to Matthew's community, the story may have functioned as a trauma relief narrative whose purpose was reminding the followers that their suffering was comparable to that of their leader - Jesus. Secondly, by emphasising the return of Jesus to Nazareth, the story counteracts Jewish accusations that linked Jesus' teaching to Egyptian soothsayers and that he was leading people away (Davies \& Allison 2004:260). However, for R.T. France Matthew's reference to Egypt emphasises the fact that Jesus is the new Moses and, more so, as 'son', he is the new Israel (Hos 11.1) (France 2007:78). In addition, it has the geographical implication that the new Israel is universal king of the magi from the East and also far south of the Roman Empire.

As niche focus, I am interested in new questions that may arise from the story if we use the migration theory. In my view, migration theory shifts attention from questions about history to sociological questions about movement; reasons for migration and challenges related to the story.

\section{Immigration theory}

The immigration theory is a fairly new interdisciplinary perspective in studying the biblical narratives. Theorising migration has been necessitated by particular broader global issues, among others the challenges associated with political violence and/or economic instability within nation states. With specific reference to Africa, after the demise of colonialism, many African states took time to stabilise their economic and political institutions. Many such disturbances were caused by infighting among competing political groups and/or external influences by former colonial powers or their backers who seek continued extraction of raw materials (McGrew 2000:239). This is true concerning several poor
African countries such as Sudan without technological capacity to make guns yet they have several guns that are presumably supplied by external mercenaries who are interested resources.

As theory, migration focuses on two fronts: firstly, the push factors which make individuals or family members forced to relocate to what they think is a safer location. For example, families or individuals living in war-torn areas are likely, if opportunity allows, to relocate to safer areas. In the recent past, we have witnessed a large migration of people from violence-prone countries, such as Somalia, Afghanistan, Libya and Iraq, seeking asylum in either neighbouring countries or, depending on finances, relocate to far-away destinations such as Australia, America or Canada (Dube 2013).

Secondly, pull factor(s) focuses on exploring attractive aspects associated with destination that forces the individual or family to leave the place of birth. Not much difference exists between the two categories because push factors make individual to consider pull factors. However, pull factors are associated with people known as economic migrants who can compare their present status and possible opportunities in the place of destination. For example, because of low salaries in most African countries, experts in various fields such as engineering and technology choose to migrate to destinations such as Australia and Canada for 'greener pastures' (Dube 2013:1).

\section{Political push factors in Palestine}

Using the migration theory, instead of starting with Matthew and questions about history, I am interested in possible push and pull factors associated with Egypt and Palestine that make the story plausible from the perspective of migration theory. I start with the question concerning whether possible forced migration could have happened during the time of Emperor Tiberius and Herod the Great. Such a question necessarily demands investigation into the Empire and particularly how the region was governed. Palestine was governed by complex legal channels. Local and domestic issues had the oversight of religious leaders and Herod who was the puppet of Rome. Pilate directly represented Roman interest in the region. Within this political context, the dominant view is that between $4 \mathrm{CE}$ and $66 \mathrm{CE}$ during the time of Nero, the region was generally peaceful and scholars talk of booms in population and prosperity in the region (Reed 2002:90).

However, such prosperity came at the expense of ruthless power by Herod Antipas, who presided over the squashing of revolt led by Judas the Galilean in $6 \mathrm{CE}$ and ruthless execution of criminals by Pilate. Given this and taking Matthew's Sondergut, I argue that the story regarding killing of innocent children may refer specifically to persecution towards Matthew's community but also reference to the general treatment of non-class citizens by the political elite. Morten Hørning Jensen writes about both the political 
development but also how local leaders such Herod Antipas would go to ruthless extent just to keep political peace for Rome (Jensen 2006:9). Such evidence gives indirect evidence to Matthew's story that because of political violence, some families such as that of Joseph and Mary may have chosen to leave the region for safety among growing settlement of Jews in Alexandria. The conclusion is that no clear event during the time of Tiberius or Herod makes a plausible push factor to Matthew's story.

\section{Pull factors - Egypt as a political safe destination}

While push factor may have existed, I am of the view that pull factors associated with Egypt plausibly read the story better. Firstly, during the last half of the last BCE, Egypt had established itself as the political hub of the rest of the Empire. The long rule of the Ptolemy dynasty came to an end with the rule of Cleopatra. Since then, events changed from 31 BCE when Caesar Octavian, who assumed the throne as Augustus, become politically strong in the West and later defeated Antony and his 'wife' Cleopatra to take control of the rest of the East, including the fertile and strategic province of Egypt (Lewis 1983:53). Having dominated the East, Octavius devised a strategy to secure his grip over Egypt. In doing so, he replaced all the top political leaders with his own - the praefectus Aegypti, who directly reported to him, thus neutralising all potential insurrection (Lewis 1983:53). To the peasants, the coming of the Romans and the departure of menacing Antiochus (in the North) and the detested Persians, was a welcome move (Bowman 1996:27). The Romans were viewed as saviours by the locals. Egypt became a peaceful place.

On the other hand, although viewed negatively even by the former Egyptian administration of Cleopatra and Antony, events did not change in Palestine where the Herodian dynasty remained intact. Politically, to those in the North, especially Palestine, Egypt was politically an attractive destination. Commenting on political events happening at that time, Bowman (1996) says the political development of peace and prosperity:

[E]ncouraged a shift of gravity towards the delta where many of the immigrants from the Hellenised Mediterranean countries must have settled. They poured into the Faynum in great numbers too and this area went through dramatic development ... the actual number of towns and villages in the valley will also have increased, as did the size of many of those already in existence. (p. 27)

In reading Matthew, there is no clear textual link of Egypt's peaceful political climate to Matthew's Sondergut. However immigration theory helps us to connect unwritten reality concerning that period. Given this and using the migration theory, one can plausibly assume that Matthew's time of writing coincided with a general fascination and appreciation of the political events in Alexandria, making Egypt a pull geographical region.
Using the theory, we can plausibly reconstruct that:

Get up! Take the Child and His mother and flee to Egypt, and remain there until I tell you; for Herod is going to search for the Child to destroy Him. (Mt 2:13)

which may be a pointer towards the safety of Egypt during that time.

Similar admission to the peace and security of Egypt comes from Josephus. Citing Josephus (Anti 13.62-73), R.T. France (2007) gives interesting insight, saying:

Egypt, the south western neighbour of Judea and now a Roman province with large Jewish population especially in Alexandria, was a natural place for Jews to seek asylum when in political danger at home, a substitute for the Jerusalem temple had even been set up by Jewish exiles in Egypt. (p. 79)

The immigration theory also allows us to assume peoples' direction of movement. Given that during that time information regarding changes in political fortune took time to reach from one region to the other, one can assume that Matthew's location in telling this story is important. Scholars think that Matthew was a Hellenistic Antiochean Jew who writes during social tension between Judaisers and Hellenistic Jews concerning the inclusion of gentile Christians. Arguably his reference to Jesus who resides or migrates to gentile territory speaks about his social reality in diaspora. If located in multicultural Antioch, news within the region transmitted by travelled merchants, senators and dignitaries from the equestrian class would have spread regarding Egypt being annexed by Octavius. Similarly, given the large Jewish population in Alexandria, relatives in Antioch and Alexandria must have compared social events in their areas. It is claimed that Ptolemy I (305-282 BCE) forcefully transported over 100000 Jews to Egypt, many of whom were conscripted into the army and some into agriculture (Barclay 1996:17). ${ }^{1}$ Given that migrants travel to regions which their fellow countrymen talk positively about, it is possible to link Hellenistic Jews in Antioch and those in Egypt as carriers of political news.

\section{Economic pull factors - Egypt as the economic hub of the empire}

Secondly, besides the political peace associated with Egypt, it was economically a pull hub. The primary reason Octavius deposed Antony and Cleopatra was to control Egypt's resources, especially the much needed grain (Bowman 1996:25). To show how economically endowed and also politically contested the region was, no member of the senate of equestrian was allowed to journey to Egypt without imperial permission. That Egypt was economically a rich region is complemented by Strabo, the geographer who reported to Rome saying that Egypt had fertile soils from the

1.Philo of Alexander places the Jewish population in Alexandria at a million, which is very improbable given that the entire population in the region was close to 3000000 . 
rich alluvial deposits that come down when the Nile floods the delta. In Egypt agriculture was easy because of the good soils; anything that one planted, gave a harvest of plenty. Strabo comments, saying:

The land was rich in flora and mineral resources. Many plant varieties offered nutrition or other profitable products without systematic cultivation. Wild bean, material for clothing, fibre, mats, balsam, date-palms were found in abundance. In addition the region was known of its variety of wild animals - 'birds, aquatic fowl, fish, antelope, roebuck and wild boar. The eastern desert underneath it was copper, iron, including semi-precious stones such as 'agate, onyx, sadonyx, amethyst, beryl, chalcite, chalcedony, cornlian, green feldspar, garnet, quarts and turquois'. (Bowman 1996:25)

Given its riches, Octavius secured the region under his direct supervision and through prefects. Octavius' barring of senators from visiting the region was 'to exclude potential leaders of disaffection, to obviate the possibility that Egypt might again serve as base for political opposition with military backing, as it had done for Antony' (Lewis 1983:10). Concerning Egypt, Bowman (1996) further writes:

[F]or over 350 years, until the foundation of Constantinople, one of the most important aspect[s] of Egypt's role in the Roman empire was as the supplier of a considerable proportion of the grain needed to feed the population of the city of Rome ... the contribution of 20 million modii of wheat under Augustus. (p. 25)

Bowman (1986) went on to further say:

$[T]$ he arrival of the huge ships of the Alexandrian grain fleet in Italy was a political event of some significance - though not nearly as significant as the threat of their absence. (p. 38)

Egypt was a granary for Rome, which also made it a region where political conflict could happen anytime.

Using migration theory, it is possible to argue that going to Egypt via Maris would have been an economically wise decision for the holy family. In comparison to the riches of Egypt, Nazareth was not climatically endowed. Rainfall was precarious. The Markan parables being closer to the earliest tradition refer to seeds falling among thorn and rocky ground, thus giving us clues regarding the climate of the region (Kloppenborg 2006:1; Van Eck 2009). Cited by Drew Christiansen (1996), in view of the challenges associated with the refugee crisis across Europe after the Second World War, Pope Pius XII in the Exsul Familia of 1952 says:

Holy Family of Nazareth, fleeing into Egypt, is the archetype of refugee family. Jesus, Mary and Joseph, living in exile in Egypt to escape an evil king, are, for all times and all places, the models of protectors of every migrant, alien and refugee of whatever kind who, whether compelled by fear of persecution by want, is forced to leave [his] native land, [his] beloved parents and relatives, close friends, and to seek a foreign soil. (p. 7)

\section{Conclusion}

Using migration theory and in view of the archaeological information regarding the Palestinian region during the first century, the story of Joseph and family's supposed flight would not be an isolated incident. Instead, given the growing Jewish population in the Alexandrian delta, the story may act as a window to several similar stories of Jews and others who endured the desert trip to Egypt. Using the migration perspective, political and economic factors could be the push factors for families in Palestine leaving for Egypt. In addition, political and economic safety associated with Egypt could have made Egypt a place of destination. Politically, being under the direct control of Augustus the Emperor, Egypt was a more stable location. The entire land was protected by local and Roman soldiers. Even public figures such as senators and equestrians could not freely travel in Egypt without permission. As the saying goes: power attracts. As such, like many other families in a similar predicament, Joseph may not have resisted being under the ambit of the Empire. Furthermore, the rich soils deposited annually upon the delta made Egypt an agriculturally rich area. Various crops and minerals were in abundance. To Rome, Egypt was the Empire's granary of grain, and a strategic place for the Emperor to appease the hungry masses and yet also increase his political favourability. Epistemologically, immigration theory may have more to contribute in exploring movement of people and the theme about survival embedded within stories such as Jesus' flight to Egypt.

\section{Acknowledgement}

I dedicate this article to Halvor Moxnes - Prof. Emeritus at the University of Oslo, Norway and Gitte Buch-Hansen at the University of Copenhagen, Denmark who afforded me the opportunity to attend the Nordic New Testament conference in Iceland and helped in structuring the argument of this article.

\section{Competing interest}

The author declares that no competing interest exists.

\section{Author contributions}

I declare that I am the sole author of this research article.

\section{Funding}

This research received no specific grant from any funding agency in the public, commercial, or not-for-profit sectors.

\section{Data availability statement}

Data sharing is not applicable to this article as no new data were created or analysed in this study.

\section{Disclaimer}

The views and opinions expressed in this article are those of the authors and do not necessarily reflect the official policy or position of any affiliated agency of the authors. 


\section{Ethical consideration}

This article followed all ethical standards for carrying out research without direct contact with human or animal subjects.

\section{References}

Aasgaard, R., 2009, The childhood of Jesus: Decoding the Apocryphal infancy Gospel of Thomas, Wipf and Stock Publishers, Eugene, OR.

Barclay, J.M., 1996, Jews in the Mediterranean Diaspora: From Alexander to Trajan (323 BCE 117 CE), University of California Press, Richmond, CA.

Bourke, M.M., 1960, 'The literary Genus of Matthew 1-2', The Catholic Biblical Quarterly 22(2), 160-175.

Bowman, A.K., 1986, Egypt after the Pharaohs, 332 BC-AD 642: from Alexander to the Arab conquest, University of California Press, Richmond, CA.

Christiansen, D., 1996, 'Movement, asylum, borders: Christian perspectives', International Migration Review 30(1), 7-17. https://doi.org/10.1177/0197918396 03000102

Davies, W.D. \& Allison, Jr. D.C., 2004, Matthew 1-7, A\&C Black, Washington, DC.

Dube, Z., 2013, 'The Ethiopian eunuch in transit: A migrant theoretical perspective', HTS Theological Studies 69(1), 1-7. https://doi.org/10.4102/hts.v69i1.2019
France, R.T., 1981, 'The formula-quotations of Matthew 2 and the problem of communication', New Testament Studies 27(2), 233-251. https://doi.org/10.1017/ S0028688500006184

France, R.T., 2007, The Gospel of Matthew. Wm. B. Eerdmans Publishing, Grand Rapids, MI.

Jensen, M.H., 2006, Herod Antipas in Galilee: the literary and archaeological sources on the reign of Herod Antipas and its socio-economic impact on Galilee, Mohr Siebeck, Tubingen.

Kloppenborg, J.S., 2006, The tenants in the vineyard: Ideology, economics, and agrarian conflict in Jewish Palestine, Mohr Siebeck, Tubingen.

Lewis, N., 1983, Life in Egypt under Roman rule, Clarendon Press Oxford, Oxford.

McGregor, J., 2010, 'Between obligation, profit and shame: Zimbabwean migrants and the UK care industry', Zimbabwe's exodus, crisis, migration, survival, pp. 179-206, SAMP, Cape Town.

McGrew, A., 2000, 'Models of Transnational Democracy', in D. Held \& A. McGrew (eds.), The Global Transformational Reader: An Introduction to the Globalisation Debate, 2nd edn., pp. 500-529, Polity Press, Cambridge.

Reed, J.L., 2002, Archaeology and the Galilean Jesus: A re-examination of the evidence, A\&C Black, Washington, DC.

Van Eck, E., 2009, 'Interpreting the parables of the Galilean Jesus: A social-scientific approach', HTS Theological Studies 65(1), 1-12. https://doi.org/10.4102/hts. v65i1.308 